\title{
Progressive Multifocal Leukoencephalopathy in Africa-A Review
}

\section{Clara-M Schutte*}

Department of Neurology, Steve Biko Academic Hospital, University of Pretoria, South Africa

*Corresponding author: Clara- M Schutte, Department of Neurology, University of Pretoria, Steve Biko Academic Hospital, South Africa, Tel: +27 12 354 1082; Fax: +27 12354 2045; E-mail: cschutte@medic.up.ac.za

Received date: Aug 04, 2014, Accepted date: Sep 16, 2014, Publication date: Sep 22, 2014

Copyright: (c) 2014 Schutte C-M. This is an open-access article distributed under the terms of the Creative Commons Attribution License, which permits unrestricted use, distribution, and reproduction in any medium, provided the original author and source are credited.

\begin{abstract}
Progressive multifocal leukoencephalopathy caused by the JC virus, results in a lytic infection of mainly oligodendrocytes of the central nervous system in immunosuppressed patients. With the advent of the HIV pandemic, the incidence of PML has risen sharply, but very few cases from Africa have been reported, even though this continent carries a very high burden of HIV infection. Explanations for the paucity of reports of PML from Africa include non-recognition of the condition, diagnostic challenges, death due to other infections, as well as suggestions of decreased neurovirulence of African JC virus types, and interactions between these types and different HIV clades. In this report we focus on reports of cases with PML from Africa, suggesting that with the availability of more sensitive assays and greater awareness, the diagnosis of PML may be more readily made in the future.
\end{abstract}

Keywords: Progressive multifocal leukoencephalopathy; Africa; HIV

\section{Introduction}

Progressive multifocal leukoencephalopathy (PML) is a disorder of the central nervous system caused by the JC virus. The JC virus, a human polyoma virus, is found widespread over the globe. The initial subclinical infection most likely occurs early in childhood with renal excretion of the virus in approximately $30 \%$ of healthy people $[1,2]$, and global seroprevalence of $70-90 \%$ [3]. In severe immunosuppression, as in HIV-infected patients or immunocompromised patients due to malignancies or autoimmune disorders, the virus leads to a lytic infection of oligodendrocytes in the brain [4]. During the pre-HAART (highly active antiretroviral therapy) era, PML was rapidly fatal, with a median survival of $3-6$ months. PML then occurred at a prevalence of $0.9-1.8 \%$ in patients with AIDS, and at post mortem examination, 2, 4-11\% of AIDS patients had PML [5-10]. With the advent of antiretroviral therapy, several studies have shown that the incidence of PML has declined [11-13], but others disappointingly did not find a significant change $[14,15]$ and the condition still carries a substantial morbidity and mortality. Improved patient survival has been reported in some studies, with up to $50 \%$ of patients living for more than one year $[16,17]$.

Africa, and specifically sub-Saharan Africa, has a very high burden of HIV infection. In South Africa, the Department of Health estimated the national HIV prevalence among women attending antenatal clinics at $29,4 \%$ in 2009 , and $29,5 \%$ in 2011 . An alarming $10,9 \%$ incidence of HIV infection has been reported for South Africans above the age of 2 years [18]. However, in spite of the fact that neurological complications of HIV are common and so many people are living with HIV in Africa, there have been remarkably few reports of PML from Africa.

\section{Suggestions for the paucity of reports of PML from Africa}

Possible explanations for the paucity of reports of PML from Africa have been offered by various authors [19]. It may be likely that many cases of PML are not recognized, since the clinical picture and imaging may be confused with ADEM, strokes, or vasculitis. Diagnostic challenges and lack of post mortem examinations in resource-poor areas may also contribute to non-recognition of the condition. Death due to other infective conditions such as tuberculosis, which may occur at higher CD4 cell counts, may be a reason why fewer patients develop PML, which is typically (but not exclusively) seen in severe immunosuppression. There have also been suggestions that some JC virus strains may not be as neuropathogenic as others-the JC virus subtype $2 \mathrm{~B}$ was shown to be associated with a higher incidence of PML in one study [20] while type 4 had an apparently lower disease risk [21]. Interactions between JC virus types and different HIV clades have also been suggested as possible causes for a low prevalence of PML in Africa and India. In these areas, the HIV clade $C$ virus is predominant, and the possibility exists that the HIV clade $\mathrm{C}$ virus Tat is not as potent as the HIV clade B in interactions with other viruses [19]. In addition, interactions between HHV-6 and the JC virus may influence the prevalence of PML, and there may also be host genetic differences in the development of PML, since a higher prevalence of PML was seen in white males compared to African American males in one study $[22,19]$.

\section{JC virus types}

Worldwide, at least 7 JC virus types have been identified. They are classified into types according to the sequence analysis of the major capsid protein VP1 and numbered from 1 to 8 , with type 5 being found to be a minor member of type 3 [23]. Type 1 and 4 generally occur in Europeans and European Americans, while type 2A occurs most commonly in the Asian and Native American population. In Africans and African-Americans, type 3 and 6 are frequently seen; 2D and $7 \mathrm{C}$ are isolated from Asians and South Asians, and in Western Pacific people, types 2E, 8A and 8B are found [24-26]. Type 8A has only been found in Papua New Guinea up to now [27]. 
Page 2 of 5

\section{Review of reports of PML from Africa}

One of the first reports of PML in Africa came from a Ugandan study in 1988 where the condition was identified in an AIDS patient with multiple opportunistic infections [28]. The diagnosis was made on autopsy, with typical neuropathological findings of PML, but the virus was not identified [29]. Another patient who was native to Gambia but passed away in Germany, was reported in 1987 [30] to have PML as the only manifestation of AIDS caused by HIV-2. The infective agent in both of these patients was later identified by Stoner et al in 1998 [29] as JC virus; in the Gambian patient, the subtype could be identified as JC virus type 3 , which was the same type that had been identified in the urine of patients with AIDS from Tanzania in 1995 [31]. It was concluded that this patient had been infected with his native strain of JC virus from Africa and had carried this virus to Germany, rather than having been newly infected with a European type of virus. Following reports of a new type JC virus being excreted from individuals from Ghana in West Africa [32], a type 6 JC virus genotype, very closely related to the Ghana strain, was found in the brain of an African American with systemic lupus erythematosis and PML [33]. It was thus confirmed that both the type 3 and the type 6 JC virus are found in Africa, and both were capable of causing PML in humans.

In one of the few African autopsy studies of patients with HIV infection, Lucas et al [34] reported on the findings of $271 \mathrm{HIV}$-positive patients from Abidjan in the Ivory Coast, showing that PML occurred in only 4 cases $(1,5 \%)$. In Rana's study from Kenia in 2000 [35], and in Ansari's study from Botswana in 2002 [36], PML was not identified as cause of death in any patient. However, a neuropathological study of 115 African patients with AIDS who had died in Belgium, found 5, 2\% to have PML [29 quotes personal communication H Taelman].

In 1999, the four cases from the Abidjan study were examined with immunohistochemical staining and PCR amplification of JC viral genomic DNA with direct cycle sequencing [37], showing that JC virus type 3 occurred in two cases, type 6 in one case and the last case had uncommon rearrangement patterns. A suggestion was made that the lower prevalence of PML in Africa may be due to biological differences in JC virus genotypes.

Several other short reports regarding PML have been published from various centres in Africa. In a resource-limited setting in Burkina-Faso in West Africa an assumptive diagnosis of PML was made in six of $72 \mathrm{HIV}$-positive patients presenting to an internal medicine ward. Unfortunately, the cases could not be confirmed by special investigations or pathology [38]. From Malawi, two cases of PML diagnosed on CT of the brain were found in an investigation of the differential diagnosis of stroke in a setting of high HIV prevalence [39] and from South Africa, a child with PML after HAART initiation was reported in 2004 [40]. Another South African report described a young woman with a very low CD 4 count $(7 / \mathrm{uL})$ and a high viral load who had presented with seizures. CT of the brain showed lesions typical of PML and this diagnosis was later confirmed on post mortem [41].

\section{Analysis of viral genomes from Africa}

As previously discussed, type 3 and type 6 of the JC virus were described from patients from Eastern and Western Africa [29,32,33]. A laboratory study from South Africa investigated five CSF samples of patients with PML, showing that three isolates grouped with type $3 \mathrm{JC}$ virus and one with type 7-[42] these were all African patients with AIDS. Another sample from a Caucasian leukaemia patient grouped with type 2D which had previously only been described in South Asia. This study thus provided evidence that the JC virus type 3 genotype occurs as far south as South Africa - historically, it is believed that black South Africans migrated south with other people of the NigerCongo linguistic groups in the last three centuries $\mathrm{BC}$, explaining JC virus subtypes $3 \mathrm{~A}$ and B in South Africa [43]. A type 7 JC virus was seen in one African patient in this study; this may possibly be explained by the fact that many people from India settled in the KwaZulu-Natal province of South Africa in the last two centuries and this case might represent a recent transmission event. The subtype 2D isolate from a Caucasian patient might reflect a recent transmission event in Eurasia [42]. Unfortunately, this was a purely laboratorybased study and no clinical information about the patients was available. Future studies of PML should preferably involve clinicians and virologists/immunologists.

Up to 2009, a conventional nested PCR targeting the VP1 region of the virus was used to detect the JC virus in the CSF of suspected PML sufferers. Glass and Venter subsequently developed a new method using a real-time PCR assay that targets a conserved region of the JC virus genome, and utilized fluorescence resonance energy transfer (FRET) hybridization probes [44]. This assay thus targets the conserved $151 \mathrm{kB}$ region of the large $\mathrm{T}$-antigen and not the variable VP1 region. The study showed the new assay to be more sensitive than the conventional method: when using the T-antigen targeted assay, it identified the JC virus in 12 specimens of CSF of patients with suspected PML versus only 5 when using the conventional VP1 nested PCR. Phylogenetic analysis of the VP1 region subsequently identified two specimens with JC virus type 3 , two with type 4 and one with type 1 [44]; (Table 1). It had been previously suggested that the type 4 JC virus may be less neuropathogenic than other types since it was underrepresented in previous studies [45,21], but this underrepresentation may just have reflected a geographic variance of JC virus subtypes.

\begin{tabular}{|l|l|l|l|l|l|l|}
\hline Country/City & Type 1 & Type 2 & Type 3 & Type 4 & Type 6 & Type 7 \\
\hline Gambia 1998 [29] & & & 1 & & & 1 \\
\hline Abidjan 1999 [37] & & & 2 & & & 1 \\
\hline South Africa 2004 [42] & & 1 & 3 & & & \\
\hline South Africa 2009 [44] & 1 & & 2 & 2 & & \\
\hline
\end{tabular}

Table 1: JC virus types - number of cases currently described in association with PML in Africa. 
Page 3 of 5

\section{Clinical case series of patients with PML from Africa}

The largest clinical report of AIDS-related PML from southern Africa involved a retrospective study of all patients with PML who had been identified over a four and a half year period in a large tertiary referral hospital in Pretoria, South Africa in 2013 [46]. Schutte and colleagues identified 17 patients with PML in whom the JC virus was confirmed by CSF analysis using T-antigen specific fluorescence energy transfer hybridization probe real-time PCR [44]. The ages ranged from 27 to 64 years (mean 38) and 13 were HAART naïve at admission. The most common clinical manifestations included focal weakness (47\%), coordination impairment (41\%) and speech disturbances (12\%). The clinical findings are comparable to those found in other studies of PML: focal weakness occurred in $43 \%$ of patients in a study from Denmark [11], which was lower than in a report from Brazil, where this sign was seen in $75 \%$ of patients [47]. In a recent report from India, a hemiparesis occurred in $45 \%$ of patients [48]. Impaired coordination was seen in 68 and $42 \%$ of patients in the studies from Denmark and Brazil; cognitive decline as complaint was present only in $6 \%$ of patients in the South African study, which is very low when compared to the 57 and $42 \%$ in the above studies (Table 2).

\begin{tabular}{|c|c|c|c|c|}
\hline & South Africa 2013 & Denmark 2009 & Brazil 2008 & India 2013 \\
\hline Number of patients & 17 & 47 & 12 & 38 \\
\hline Median age (range) & $38(27-64)$ & $48(43-53)$ & $36(25-52)$ & $39(25-68)$ \\
\hline HAART naïve (\%) & $13(76)$ & $35(73)$ & $9(75)$ & $25(66)$ \\
\hline \multicolumn{5}{|l|}{ Clinical findings } \\
\hline Focal weakness & $47 \%$ & $43 \%$ & $75 \%$ & $45 \%$ \\
\hline Impaired coordination & $41 \%$ & $68 \%$ & $42 \%$ & $37 \%$ \\
\hline Speech disturbances & $12 \%$ & $43 \%$ & $58 \%$ & $26 \%$ \\
\hline Cognitive dysfunction & $6 \%$ & $57 \%$ & $42 \%$ & $26 \%$ \\
\hline Seizures & $6 \%$ & $13 \%$ & $8 \%$ & $13 \%$ \\
\hline Visual disturbances & $6 \%$ & - & - & $10 \%$ \\
\hline Median CD 4 count (range) & $\begin{array}{l}41 / u L \\
(11-328)\end{array}$ & $\begin{array}{l}\text { 50/uL } \\
(27-160)\end{array}$ & $\begin{array}{l}45 / \mathrm{uL} \\
(3-210)\end{array}$ & $\begin{array}{l}\text { 153/uL } \\
(50-289)\end{array}$ \\
\hline
\end{tabular}

Table 2: Comparison of clinical findings of patients with PML [46,147, and 48].

In the study by Schutte radiological imaging showed lesions typical of PML in the white matter. CT brain was performed in 15 patients and 13 had MRI studies. Two CT scans appeared normal, but on subsequent MRI studies, a single lesion was seen in both patients in the centrum semi-ovale. In four of the MRI's, multiple lesions were visible which had appeared as only single lesions on the CT brain, once again confirming the superiority of the MRI in diagnosing PML. Mean CD4 counts in the South African study were comparable to those in other studies, while the CSF analysis showed a mild lymphocytic pleocytosis in $35 \%$ of patients and elevated protein levels in $76 \%$-this is higher when compared to other studies where pleocytosis occurred in $15 \%$ of patients and elevated protein levels in $20-30 \%$ [46].

Interestingly, the large majority of patients from the study by Schutte and colleagues were seen during the last 18 months of the study period (12 of 17 patients), possibly suggesting that the disorder is becoming more frequent, or that the diagnosis is currently more readily made. However, this was a retrospective study and a multicentre prospective data collection of PML cases in southern Africa would be an interesting research endeavour. Analysing the JC virus types and correlating these to the clinical picture may in addition also be of value for future research. In another study from the same neurology unit in Pretoria [49], an analysis of the clinical mortality data from 2006-2012 showed that PML was the cause of death in 5\% of HIV-positive patients, which is comparable to older neuropathological studies from first world countries [50,51].

\section{PML related to Immune reconstitution inflammatory syndrome (IRIS) in Africa}

After initiation of HAART, some patients may unfortunately develop an IRIS which is characterized by a sudden worsening of a previously acquired infectious process in spite of immunological recovery [52]. The most common culprits in this setting are tuberculosis and cryptococcal infection [53], but PML associated IRIS is also seen [54]. This condition emerges as one of the new treatment challenges related to JV virus infection in developed countries [55].

Antiretroviral therapy has become available more readily recently throughout the world. In South Africa, the number of patients on antiretroviral therapy has increased from less than 2000 in 2003 to 1,79 million in 2011 after an initial hesitancy to implement HAART programs [56]. The risk factors for the development of this syndrome include very low CD4 counts, rapid decrease of viral load, presence of active or subclinical opportunistic infections when antiretroviral therapy is started, and HAART naive patients [57]. There have not been many reports of PML related IRIS from Africa up to now. One recent report from South Africa which investigated central nervous system disorders after starting antiretroviral therapy, found neurological IRIS only related to tuberculosis and cryptococcosis in their patients. No patient with PML was seen within the one year of the study [53]. The short duration of this study is a limitation and longer periods of data collection may still show cases with PML IRIS in South Africa. The previously mentioned report of a child with PML [40] described a 12-year old boy from Cape Town, South Africa, with 
advanced HIV infection who developed cerebellar signs and a hemiparesis within five weeks of antiretroviral therapy commencement as an example of PML related to IRIS. This child improved after a course of glucocorticosteroid therapy while continuing antiretroviral medication. In the study by Schutte and colleagues, two patients were considered to have had PML related to IRIS [46]. One patient had several white matter lesions in the brainstem and cerebellum, with some cerebellar lesions showing ring enhancement post gadolinium. The patient had started antiretroviral therapy about six months before - this might be considered quite a long time for IRIS as most patients develop this syndrome within two months of starting HAART [58]. The other patient deteriorated after HAART had been started while in the ward; she improved slightly after steroid treatment. The expectation is that PML IRIS will be seen more frequently in the next few years.

\section{Conclusion}

PML remains a diagnostic challenge in resource-poor areas of the world. The newer assays which target a conserved region of the JC virus genome and utilize fluorescence resonance energy transfer (FRET) hybridization probes show an improved sensitivity in detecting the JC virus in the CSF of African patients with suspected PML. The African JC virus types 3 and 6 are capable of causing PML and types 1,2D, 4 and 7 have also been found in association with PML in Africa. Even in regions with HIV clade C predominance, patients with HIV associated PML are increasingly being described, with possibly even similar incidences as in previous studies from developed countries.

\section{References}

1. Koralnik IJ (2006) Progressive multifocal leukoencephalopathy revisited: Has the disease outgrown its name? Ann Neurol 60: 162-173.

2. Kitamura T, Aso Y, Kuniyoshi N, Hara K, Yogo Y (1990) High incidence of urinary JC virus excretion in nonimmunosuppressed older patients. J Infect Dis 161: 1128-1133.

3. Shackelton LA, Rambaut A, Pybus OG, Holmes EC (2006) JC virus evolution and its association with human populations. J Virol 80: 9928-9933.

4. Major EO, Amemiya K, Tornatore CS, Houff SA, Berger JR (1992) Pathogenesis and molecular biology of progressive multifocal leukoencephalopathy, the JC virus-induced demyelinating disease of the human brain. Clin Microbiol Rev; 5:49-73.

5. Anders KH, Guerra WF, Tomiyasu U, Verity MA, Vinters HV (1986) The neuropathology of AIDS. UCLA experience and review. Am J Pathol 124: 537-558.

6. Levy RM, Bredesen DE, Rosenblum ML (1985) Neurological manifestations of the acquired immunodeficiency syndrome (AIDS): experience at UCSF and review of the literature. J Neurosurg 62: 475-495.

7. Burns DK, Risser RC, White CL 3rd (1991) The neuropathology of human immunodeficiency virus infection. The Dallas, Texas, experience. Arch Pathol Lab Med 115: 1112-1124.

8. Masliah E, DeTeresa RM, Mallory ME, Hansen LA (2000) Changes in pathological findings at autopsy in AIDS cases for the last 15 years. AIDS 14: 69-74.

9. Berger JR, Kaszovitz B, Donovan J, Dickinson G. (1987) Progressive Multifocal Leukoencephalopathy Associated with Human Immunodeficiency Virus Infection: A Review of the Literature with a Report of Sixteen Cases. Ann Intern Med 107:78-87.

10. Kure K, Llena JF, Lyman WD, Soeiro R, Weidenheim KM, et al. (1991) Human immunodeficiency virus-1 infection of the nervous system: an autopsy study of 268 adult, pediatric, and fetal brains. Hum Pathol 22: 700-710.

11. Engsig FN, Hansen AB, Omland LH, Kronborg G, Gerstoft J, et al. (2009) Incidence, clinical presentation, and outcome of progressive multifocal leukoencephalopathy in HIV-infected patients during the highly active antiretroviral therapy era: a nationwide cohort study. J Infect Dis 199: 7783.

12. d'Arminio Monforte A, Cinque P, Mocroft A, Goebel FD, Antunes F, et al. (2004) Changing incidence of central nervous system diseases in the EuroSIDA cohort. Ann Neurol 55: 320-328.

13. Grabar S Lanoy E, Allavena C, Mary-Krause M, Bentata M, et al. (2008) Causes of the first AIDS-defining illness and subsequent survival before and after the advent of combined antiretroviral therapy. HIV Med 9: 246-256.

14. Ammassari A, Cingolani A, Pezzotti P, De Luca DA, Murri R, et al. (2000) AIDS-related focal brain lesions in the era of highly active antiretroviral therapy. Neurology 55: 1194-1200.

15. Sacktor N Lyles RH, Skolasky R, Kleeberger C, Selnes OA, et al. (2001) HIV-associated neurologic disease incidence changes:: Multicenter AIDS Cohort Study, 1990-1998. Neurology 56: 257-260.

16. Dworkin MS, Wan PC, Hanson DL, Jones JL (1999) Progressive multifocal leukoencephalopathy: improved survival of human immunodeficiency virus-infected persons in the protease inhibitor era. J Infect Dis 180: 621-625.

17. Antinori A, Cingolani A, Lorenzini P, Giancola ML, Uccella I, et al. (2003) Italian Registry Investigative Neuro AIDS Study Group. Clinical epidemiology and survival of progressive multifocal leukoencephalopathy in the era of highly active antiretroviral therapy: data from the Italian Registry Investigative Neuro AIDS (IRINA). J Neurovirol 1:47-53.

18. National Department of Health $(2010,2012)$ National Antenatal Sentinel HIV and Syphilis Prevalence Survey in South Africa, 2009, and 2011. Pretoria: DoH.

19. Shankar SK, Satishchandra P, Mahadevan A, Yasha TC, Nagaraja D, et al. (2003) Low prevalence of progressive multifocal leukoencephalopathy in India and Africa: is there a biological explanation? J Neurovirol 9 Suppl 1: 59-67.

20. Agostini HT, Ryschkewitsch CF, Baumhefner RW, Tourtellotte WW, Singer EJ, et al. (2000) Influence of JC virus coding region genotype on risk of multiple sclerosis and progressive multifocal leukoencephalopathy. J Neurovirol 6 Suppl 2: S101-108.

21. Dubois V, Moret H, Lafon ME, Brodard V, Icart J, et al. (2001) JC virus genotypes in France: molecular epidemiology and potential significance for progressive multifocal leukoencephalopathy. J Infect Dis 183: 213-217.

22. Holman RC, Török TJ, Belay ED, Janssen RS, Schonberger LB (1998) Progressive multifocal leukoencephalopathy in the United States, 1979-1994: increased mortality associated with HIV infection. Neuroepidemiology 17: 303-309.

23. Ferenczy MW, Marshall LJ, Nelson CDS, Atwood WJ, Nath A, et al. (2012) Molecular Biology, Epidemiology, and Pathogenesis of Progressive Multifocal Leukoencephalopathy, the JC Virus-induced Demyelinating Disease of the Human Brain. Clin Microbiol rev 25: 471-506.

24. Agostini HT, Ryschkewitsch CF, Stoner GL (1998) JC virus Type 1 has multiple subtypes: three new complete genomes. J Gen Virol 79 : 801-805.

25. Cui X, Wang JC, Deckhut A, Joseph BC, Eberwein P, et al. (2004) Chinese strains (Type 7) of JC virus are afro-asiatic in origin but are phylogenetically distinct from the Mongolian and Indian strains (Type 2D) and the Korean and Japanese strains (Type 2A). J Mol Evol 58: 568-583.

26. Yanagihara R, Nerurkar VR, Scheirich I, Agostini HT, Mgone CS, et al. (2002) JC virus genotypes in the western Pacific suggest Asian mainland relationships and virus association with early population movements. Hum Biol 74: 473-488. 
27. Jobe DV, Friedlaender JS, Mgone CS, Agostini HT, Koki G, et al. (2001) New JC virus (JCV) genotypes from papua new guinea and micronesia (type 8 and type 2E) and evolutionary analysis of 32 complete JCV genomes. Arch Virol 146: 2097-2113.

28. Lucas SB, Sewankambo N, Nambuya A, Nsubuga P, Goodgame R et al. (1988) The morbid anatomy of African AIDS. In: Giraldo G, BethGiraldo E, Clumeck N, Gharbi MR, Kyalwazi SK, de The G (eds). AIDS and associated cancers in Africa. Basel, Karger, pp- 124- 133.

29. Stoner GL, Agostini HT, Ryschkewitsch CF, Mazló M, Gullotta F, et al. (1998) Detection of JC virus in two African cases of progressive multifocal leukoencephalopathy including identification of JCV type 3 in a Gambian AIDS patient. J Med Microbiol 47: 733-742.

30. Ruebsamen-Waigman H, Adamski M, von Briesn H et al. (1987) Lethal progressive multifocal leukoencephalopathy in an HIV-2 infected person as the only AIDS manifestation. AIDS-FORSCHUNG (AIFO) 2: 572 575.

31. Agostini HT, Brubaker GR, Shao J, Levin A, Ryschkewitsch CF, et al. (1995) BK virus and a new type of JC virus excreted by HIV-1 positive patients in rural Tanzania. Arch Virol 140: 1919-1934.

32. Guo J Kitamura T, Ebihara H, Sugimoto C, Kunitake T, et al. (1996) Geographical distribution of the human polyomavirus JC virus type A and B and isolation of a new type from Ghana. J Gen Virol 77 : 919-927.

33. Agostini HT, Ryschkewitsch CF, Stoner GL (1998) Complete genome of a JC virus genotype type 6 from the brain of an African American with progressive multifocal leukoencephalopathy. J Hum Virol 1:267-272.

34. Lucas SB, Hounnou A, Peacock C, Beaumel A, Djomand G, et al. (1993) The mortality and pathology of HIV infection in a west African city. AIDS 7: 1569-1579.

35. Rana FS, Hawken MP, Mwachari C, Bhatt SM, Abdullah F, et al. (2000) Autopsy study of HIV-1-positive and HIV-1-negative adult medical patients in Nairobi, Kenya. J Acquir Immune Defic Syndr 24: 23-29.

36. Ansari NA, Kombe AH, Kenyon TA, Hone NM, Tappero JW, et al. (2002) Pathology and causes of death in a group of 128 predominantly HIV-positive patients in Botswana, 1997-1998. Int J Tuberc Lung Dis 6: 55-63.

37. Chima SC, Agostini HT, Ryschkewitsch CF, Lucas SB, Stoner GL (1999) Progressive multifocal leukoencephalopathy and JC virus genotypes in West African patients with acquired immunodeficiency syndrome: a pathologic and DNA sequence analysis of 4 cases. Arch Pathol Lab Med 123: 395-403.

38. Millogo A, Sawadogo AB, Lankoandé D, Ouédraogo I (2001) [Diagnostic problems of expansive intracranial process in HIV infected patients of the Bobo-Dioulasso Central Hospital (Burkina Faso)]. Bull Soc Pathol Exot 94: 315-318.

39. Kumwenda JJ, Mateyu G, Kampondeni S, van Dam AP, van Lieshout L, et al. (2005) Differential diagnosis of stroke in a setting of high HIV prevalence in Blantyre, Malawi. Stroke 36: 960-964.

40. Nuttall JJ, Wilmshurst JM, Ndondo AP, Yeats J, Corcoran C et al. (2004) Progressive multifocal leukoencephalopathy after initiation of highly active antiretroviral therapy in a child with advanced human immunodeficiency virus infection: a case of immune reconstitution inflammatory syndrome. Pediatr Infect Dis J 23: 683- 685.

41. Modi M (2008) Progressive multifocal leucoencephalopathy--a case report. S Afr Med J 98: 263-264.

42. Venter M, Smit SB, Leman P, Swanepoel R (2004) Phylogenetic evidence of widespread distribution of genotype $3 \mathrm{JC}$ virus in Africa and identification of a type 7 isolate in an African AIDS patient. J Gen Virol 85: 2215-2219.
43. Olivier R. (1991) The African Experience. Chatham: Pimlico.

44. Glass AJ, Venter M (2009) Improved detection of JC virus in AIDS patients with progressive multifocal leukoencephalopathy by T-antigen specific fluorescence resonance energy transfer hybridization probe realtime PCR: evidence of diverse JC virus genotypes associated with progressive multifocal leukoencephalopathy in Southern Africa. J Med Virol 81: 1929-1937.

45. Agostini HT, Ryschkewitsch CF, Singer EJ, Baumhefner RW, Stoner GL (1998) JC virus type 2B is found more frequently in brain tissue of progressive multifocal leukoencephalopathy patients than in urine from controls. J Hum Virol 1: 200-206.

46. Schutte CM, Ranchhod N, Kakaza M, Pillay M (2013) AIDS-related progressive multifocal leukoencephalopathy (PML): a retrospective study from Pretoria, South Africa. S Afr Med J 103: 399-401.

47. Vidal JE, Penalva de Oliveira AC, Fink MC, Pannuti CS, Trujillo JR (2008) Aids-related progressive multifocal leukoencephalopathy: a retrospective study in a referral center in São Paulo, Brazil. Rev Inst Med Trop Sao Paulo 50: 209-212.

48. Netravathi M Mahadevan A, Satishchandra P, Shobha N, Mailankody P, et al. (2013) Progressive multifocal leukoencephalopathy (PML) associated with HIV Clade C--is not uncommon. J Neurovirol 19: 198-208

49. Schutte CM (2013) Analysis of HIV-related mortality in a tertiary South African neurology unit, 2006- 2012S Afr J HIV Med 14: 121- 124.

50. Lang W, Miklossy J, Deruaz JP, Pizzolato GP, Probst A, et al. (1989) Neuropathology of the acquired immune deficiency syndrome (AIDS): a report of 135 consecutive autopsy cases from Switzerland. Acta Neuropathol 77: 379-390.

51. Berger JR, Concha M (1995) Progressive multifocal leukoencephalopathy: the evolution of a disease once considered rare. J Neurovirol 1: 5-18.

52. Shelburne SA, Hamill RJ, Rodriguez-Barradas MC, Greenberg SB, Atmar $\mathrm{RL}$ et al (2002) Immune reconstitution inflammatory syndrome: emergence of a unique syndrome during highly active antiretroviral therapy. Medicine (Baltimore) 81: 213.

53. Asselman V, Thienemann F, Pepper DJ, Boulle A, Wilkinson RJ, et al. (2010) Central nervous system disorders after starting antiretroviral therapy in South Africa. AIDS 24: 2871-2876.

54. Müller M, Wandel S, Colebunders R, Attia S, Furrer H, et al. (2010) Immune reconstitution inflammatory syndrome in patients starting antiretroviral therapy for HIV infection: a systematic review and metaanalysis. Lancet Infect Dis 10: 251-261.

55. Tan K, Roda R, Ostrow L, McArthur J, Nath A (2009) PML-IRIS in patients with HIV infection: clinical manifestations and treatment with steroids. Neurology 72: 1458-1464.

56. Johnson LF (2012) Access to antiretroviral treatment in South Africa, 2004- 2011. SA J HIV Med 13: 1-14.

57. Berger JR (2011) The clinical features of PML. Cleve Clin J Med 78 Suppl 2: S8-12

58. Cinque P, Bossolasco S, Brambilla AM, Boschini A, Mussini C, et al. (2003) The effect of highly active antiretroviral therapy-induced immune reconstitution on development and outcome of progressive multifocal leukoencephalopathy: study of 43 cases with review of the literature. J Neurovirol 1:73. 